\title{
A perifériás verőérbetegek életminőségét vizsgáló angol nyelvü kérdőív magyar adaptálása
}

\author{
Horváth Lilla ${ }^{1}$ - Boncz Imre dr. ${ }^{1}$ - Kívés Zsuzsanna ${ }^{1}$ - Németh Noémi ${ }^{1}$ \\ Biró Katalin dr. ${ }^{2}$ - Fendrik Krisztina dr. ${ }^{2}$ - Koltai Katalin dr. ${ }^{2}$ \\ Késmárky Gábor dr. ${ }^{2}$. Endrei Dóra dr. ${ }^{1,2}$
}

${ }^{1}$ Pécsi Tudományegyetem, Egészségtudományi Kar, Egészségbiztosítási Intézet, Pécs ${ }^{2}$ Pécsi Tudományegyetem, Általános Orvostudomány Kar, Klinikai Központ, I. Belgyógyászati Klinika, Angiológiai Tanszék, Pécs

\begin{abstract}
Bevezetés: A perifériás verőérbetegség napjaink egyik világméretú népegészségügyi problémája, több mint 200 millió embert érint világszerte. A Peripheral Artery Disease Quality of Life (PADQOL) kérdő́ivet azzal a céllal fejlesztették ki, hogy a betegség fizikai tünetein kívül annak szubjektív betegségterhét, pszichoszociális és emocionális hatásait is vizsgálja.

Célkitüzés: Az eredeti, angol nyelvű PADQOL betegségspecifikus, önkitöltős kérdőív magyar nyelvű, érvényes változatának kifejlesztése, annak fordítása, kultúrközi adaptációja és magyar nyelvi validálása.

Módszerek: Az életminőség-kérdőív lingvisztikai validálása nemzetközi protokoll alapján történt: két szakfordító külön-külön lefordította a kérdőívet angol forrásnyelvről magyarra; egy harmadik szakfordító bevonásával elkészült a két verzió szintézise, majd azt két, angol anyanyelvú fordító visszafordította angol forrásnyelvre, amit konszenzusmegbeszélés követett. A „pre-final” magyar verzió érthetőségét 30, angiológiai járó és fekvő beteg bevonásával, kognitív interjúk lefolytatásával, pilotvizsgálat során teszteltük. A PADQOL kérdőív faktorstruktúrájának feltárásához faktoranalízist végeztünk, az alskálák megbízhatóságát, a tételek belső konzisztenciáját a Cronbach-alfa-együttható kiszámításával vizsgáltuk. Az elemzésekhez IBM SPSS 23.0 programcsomagot használtunk.

Eredmények: A PADQOL nyelvi validálása jelentéstani, tapasztalati és idiomatikus ekvivalencia tekintetében nem jelentett nehézséget. A kognitív interjúk során egy kérdés esetén tapasztaltunk értelmezési nehézséget. A kérdőív „pre-final” verziója tartalmilag és nyelvileg könnyen érthető, kitöltése nem okoz nehézséget. Az egyes dimenziók Cronbach- $\alpha$-értéke 0,624 és 0,887 között volt. A legrosszabb értéket a Félelem és bizonytalanság (score-átlag: 14,07) életminőség-dimenzió mutatta.

Következtetés: Létrehoztuk a PADQOL kérdőív végső magyar verzióját, mely mérőeszköz alkalmas a nyelvi és kultúrközi adaptáció következő lépésének elvégzésére, nagyobb betegpopuláción történő pszichometriai és klinikometriai vizsgálat által a perifériás verőérbetegek életminőségének, szubjektív betegségterhének felmérését célzó validálásra. Orv Hetil. 2020; 161(51): 2153-2161.
\end{abstract}

Kulcsszavak: életminőség, validálás, PADQOL, perifériás verőérbetegség

\section{Hungarian adaptation of the Peripheral Artery Disease Quality of Life questionnaire}

Introduction: Peripheral artery disease is one of the greatest, global public health concerns affecting more than 200 million people worldwide. The Peripheral Artery Disease Quality of Life questionnaire was developed to assess the subjective disease burden of peripheral artery disease, by focusing on psychosocial and emotional effects besides physical symptoms and functional limitations.

Objective: To develop the valid Hungarian version of the original PADQOL via the standard linguistic validation and cross-cultural adaptation procedure.

Methods: The linguistic validation was conducted according to an international protocol: two independent forward translations, a synthesis of the translations, back translations and consensus team review. The pilot-testing of the 'prefinal' Hungarian version was conducted via cognitive interviews with 30 in- and outpatients attending the Department of Angiology. Factor analysis was performed, Cronbach-alpha values were calculated to establish the reliability of subscales and to determine the internal consistency if items. IBM SPSS 23.0 was used. 
Results: The linguistic validation of PADQOL into Hungarian posed no difficulties in terms of semantic, experiential and idiomatic equivalence. One item was found difficult to interpret during cognitive interviewing. The 'pre-final' version of the questionnaire was easy to understand and complete. Cronbach-alpha values of factors ranged between 0.624 and 0.887 . The lowest value was that of factor 4: Fear and Uncertainty (mean score: 14.07).

Conclusion: The linguistic validation of PADQOL into Hungarian was successful, the final Hungarian version is a tool that should reveal valuable insights with regard to subjective disease burden of patients living with peripheral artery disease subsequent to psychometric and clinicometric validation on a larger patient population.

Keywords: quality of life, linguistic validation, PADQOL, peripheral artery disease

Horváth L, Boncz I, Kivés Zs, Németh N, Biró K, Fendrik K, Koltai K, Késmárky G, Endrei D. [Hungarian adaptation of the Peripheral Artery Disease Quality of Life questionnaire]. Orv Hetil. 2020; 161(51): 2153-2161.

(Beérkezett: 2020. május 25; elfogadva: 2020. június 27.)

\section{Rövidítések}

ESC $=$ (European Society of Cardiology) Európai Kardiológiai Társaság; EUROSTAT = az Európai Unió Statisztikai Hivatala; EuroQoL-5D = (European Quality of Life -5 Dimensions $)$ az Európai Életminőség Kérdőív 5 kérdéses változata; HRQOL = (Health-Related Quality of Life) egészségi állapottal összefüggó életminőség; KMO = Kaiser-Meyer-Olkin; KSH = Központi Statisztikai Hivatal; LEAD $=($ lower extremity artery disease) alsó végtagi veróérbetegség; $\mathrm{PAD}=$ (peripheral artery disease) perifériás veróérbetegség; PADQOL = $($ Peripheral Artery Disease Quality of Life) perifériás verőérbetegséggel élők életminősége; SF-36 = (36-Item Short Form Survey) a Rand Corporation 36 kérdéses rövid, az egészségi állapottal kapcsolatos kérdóíve; VASCUNET = az Európai Érsebészeti Társaság (European Society for Vascular Surgery) adatbázisa; VASCUQOL $=($ Vascular Quality of Life $)$ érbetegséggel élők életminősége; WIQ = (Walking Impairment Questionnaire) Járásromlás Kérdőív

A perifériás veróérbetegség (PAD), vagy alsó végtagi verőérbetegség (LEAD), az alsó végtagot érintő progreszszív, atheroscleroticus betegség, mely diffúz, degeneratív folyamat. Az érszúkü̈let miatt kialakult elégtelen vérellátás és oxigenizáció terhelésre, majd nyugalomban is jelentkezó fájdalmat (claudicatio intermittens, ischaemiás claudicatio) vagy súlyosabb esetben kritikus végtagischaemiát okoz [1]. Az érszúkület sokáig nem okoz tüneteket; sokszor akkor kerül felismerésre, amikor a járás korlátozottá válik a romló vérellátás következtében, vagy a lábon nem gyógyuló seb, fekély alakul ki. Az artériás fekély okozta fájdalmat tovább komplikálhatja a lokális infekció vagy gyulladás. Mindez komoly panaszokat, a hétköznapi feladatok ellátásának korlátozottságát jelenti, jelentôs életminőség-romlást okoz, súlyos esetben akár végtag-amputációhoz vezet [2-4].

A PAD jelentős prediktora a szisztémás vascularis betegség mértékének. Egy 2013-ban megjelent, szisztematikus áttekintő tanulmány rámutatott arra, hogy a PAD a harmadik az atheroscleroticus cardiovascularis halálozások okainak sorában, a koszorúér-betegség és a stroke után. E tanulmány szerint a világban 2010-ben 202 mil- lióra volt tehető a PAD-ban szenvedő betegek száma, ami a vizsgált 10 év során (2000-2010) 28,7\%-os növekedést jelentett. A PAD prevalenciája növekvő tendenciát mutat, ami jelentős világméretü terhet jelent nemcsak a betegek, hanem a társadalom és az egészségbiztositási rendszerek számára is [5]. A European Society of Cardiology (ESC) 2017. évi terápiás ajánlása alapján a PAD és a diabetes állnak az első helyen az alsó végtagi amputációk hátterében világviszonylatban [6].

Magyarországon az összes halálozás több mint feléért a szív- és érrendszeri megbetegedések felelósek. A PAD a leginkább az alsó végtag verőereiben lép fel, az érszúkület, az érelmeszesedés egyik jele és megjelenési formája. Magyarországon kb. 400000 embert érint; az 50 éves korosztályban az előfordulási gyakorisága jelentôsen megnő, akár a 20\%-ot is elérheti [7-9]. A PAD-ban szenvedő betegeknek jelentősen megnő a cardio- vagy cerebrovascularis betegségekből eredő mortalitása, ebben a populációban kétszer nagyobb a szívinfarktus vagy a stroke bekövetkeztének veszélye [10-11]. Pécsvárady és mtsai kimutatták, hogy a PAD-betegek halálozásának hátterében 70-80\%-ban cardiovascularis ok áll [7]. Fontos a komorbiditások felmérése is, többek között a magasvérnyomás-betegség, a dyslipidaemia, a diabetes mellitus megléte. A dohányzás megléte egyértelmú rizikótényező [11-13].

A PAD-dal összefüggő életminőség-változás, a betegség súlyossága és az életminőség kapcsolatának vizsgálata az elmúlt években ismertebbé vált [14]. A perifériás verőérbetegek életminőség- és betegségteher-eredményeire is számos kutatás rámutat. Bebizonyosodott, hogy PAD esetén az egészségi állapottal összefüggő életminőség (Health-Related Quality of life, HRQOL) a Fontaine-stádiumok mentén fokozatosan romlik [15]. Magyarországon a PAD és az életminőség összefüggéseit felmérő vizsgálatok nagy részét általános (generikus) mérőeszközzel, az EuroQol (EQ-5D) életminőség-kérdőívvel végezték [15, 16]. Az életminőség-kutatásokban a generikus és betegségspecifikus kérdőívek együttes használata kívánatos $[16,17]$. Számos kutatás rámutatott arra, hogy az általános életminőség-mérók mellett a 
PAD szubjektív betegségterhének, a betegség pszichoszociális és emocionális hatásainak értékelésére a betegségspecifikus kérdőívek jól használhatók [18, 19].

A PADQOL (Peripheral Artery Disease Quality of Life - perifériás verőérbetegséggel élők életminősége) az első olyan önkitöltős, betegségspecifikus állapotfelmérő, melyet azért fejlesztettek ki, hogy a perifériás érbetegség okozta fizikai tüneteken kívül a betegség pszichoszociális és emocionális hatásait is vizsgálja, rávilágítva a páciensek életminőség-értékelésének hátterében meghúzódó szubjektív, egyéni aspektusokra, továbbá az esetleges szociális vagy pszichológiai segítségnyújtás szükségességére egyaránt [19]. Az elmúlt években hazánkban is egyre nagyobb jelentőséget kaptak az életminőséggel kapcsolatos kutatások, a betegek által megfogalmazott eredményességi mutatók (patient-reported outcomes) [20-22].

Kutatásunk célja az eredeti angol nyelvű PADQOL mérőeszköz lingvisztikai validálása és kulturális adaptációja, a magyar nyelven is érvényes, tudományos szempontból megbízható változat létrehozása. A PADQOL magyar nyelvű verziójának létrehozásával egy újabb mérőeszközt kívánunk biztosítani a perifériás érbetegek szubjektív betegségterhének még pontosabb mérésére és értékelésére, ami által a magyar betegeken végzett gyógyszeres kezelések vagy klinikai beavatkozások hatékonysága, az ezek révén elért életminőség-nyereség öszszemérhetôvé és összehasonlíthatóvá válhat a külföldi adatokkal.

\section{Adatok és módszerek}

\section{A PADQOL kérdőin}

Az eredeti PADQOL kérdőívet Treat-Jacobson és mtsai 38, tünetekkel élö, claudicatio intermittensben, nyugalmi ischaemiás fájdalomtól szenvedő, szövetvesztésen, illetve amputáción átesett beteggel lefolytatott interjú alapján fejlesztették ki az Egyesült Államokban azzal a céllal, hogy olyan mérőeszközt alkossanak, amely rámutat a PAD-betegeknek a betegséggel való együttélés során tapasztalt szubjektív érzéseire, problémáira. A kérdőívnek az első fázisban megalkotott 65 tétele egy többlépcsős, összesen 297 páciens bevonásával folytatott validálási folyamat végeredményeként 38 tételre szúkült [19].

A szerzők célja az volt, hogy olyan, könnyen érthető tételeket alkossanak, melyekkel a perifériás verőérbete- gek könnyen tudnak azonosulni, melyeket relevánsnak éreznek. A PAD jelentősen befolyásolja az életminőséget, beleértve a családdal, barátokkal való viszonyt, és nagymértékben ronthatja a betegek szubjektív énképét is. A PADQOL kérdőív - a nyugalomban vagy a járás során észlelt fájdalom okozta fizikális korlátozottságra irányuló kérdéseken túl - olyan állításokat is tartalmaz, amelyek a PAD-nak a mindennapi élet során megélt szubjektív betegségterhét, a betegségnek az életminőségre, a beteg jóllétére gyakorolt hatásait is érintik.

A 38 tételes PADQOL állapotfelmérő az egészséggel összefüggő életminőséget 5 dimenzióban vizsgálja: Társas kapcsolatok és interakciók (9 tétel), Önkép és érzelmek (7 tétel), Tünetek és testi funkcióbeli korlátozottság (8 tétel), Félelem és bizonytalanság (4 tétel), Pozitív adaptáció (7 tétel), továbbá 3 különálló tétel vonatkozik a munka, a szexuális élet és a közeli kapcsolatok területére. A kérdőív tételenként 6 válaszlehetőséget kínál egy Likert típusú skálán; a válaszopciók a ,teljesen egyetértek” - „egyáltalán nem értek egyet” végpontok között helyezkednek el. A PADQOL gyorsan és könnyen kitölthető, a szerzők szerint az átlagos kitöltési idő 9 perc. [19].

\section{Nyelvi validálás}

A PADQOL kérdőív lingvisztikai validálási folyamatát nemzetközileg elfogadott protokoll alapján $[23,24]$ végeztük (1. ábra). Az első lépésben a levelező szerzőtől, prof. Treat-Jacobsontól megkértük a PADQOL kérdőív nyelvi validálásához és kulturális adaptálásához az engedélyt, a kérdőív végleges hivatalos verzióját és a kiértékelés módjára vonatkozó instrukciókat, amelyeket meg is kaptunk. Ezt követően a PADQOL kérdőív minden egyes elemét - a bevezető részt, a kérdéseket, a válaszopciókat és a statisztikai kiértékelési útmutatót - két hivatásos szakfordító, egy ún. „informált” és egy „nem informált” fordító fordította magyarra. Az ,informált” szakfordító egészségügyi és orvosi szakfordító-szaktolmács képesítéssel rendelkezik, a „,nem informált” szakfordító gazdasági és társadalomtudományi szakfordító és szaktolmács. Mivel a kérdőív önkitöltős jellegű, mindkét fordító számára hangsúlyoztuk, hogy a szigorú nyelvi megfeleltetés helyett inkább a fogalmi megfeleltetésre törekedjenek, hiszen célunk egy, a magyar átlag-betegpopuláció számára könnyen érthető és egyszerüen kitölthető kérdőív létrehozása volt. Az ,informált” szakfordí-

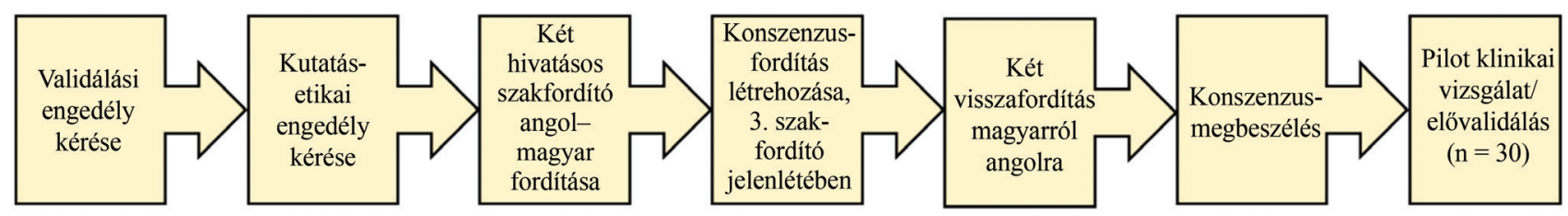

1. ábra

A PADQOL kérdőív lingvisztikai validálási folyamata

PADQOL = perifériás verőérbetegséggel élők életminősége 
tó tájékoztatást kapott a kérdőív céljáról és az általa vizsgált betegségről. Mivel a PADQOL nem tartalmaz orvosi szakkifejezéseket a PAD betúszón kívül, a validálási protokoll alapján várható különbség - vagyis hogy az orvosi-egészségügyi szakterületen jártas szakfordító a betegek számára kevésbé könnyen érthető fordítási megoldásokat kínál majd a más területen jártas szakfordítóval szemben - nem volt jelentős. A tapasztalati és idiomatikus ekvivalencia tekintetében a fordítási folyamat során a fordítók nem tapasztaltak nehézséget $[25,26]$.

A következő lépésben egy harmadik szakfordító-szaktolmács bevonásával a három szakfordító megvitatta a fordítási megoldásokat, és létrehozták az első magyar konszenzusverziót. Ezt követte a közösen létrehozott magyar verzió visszafordítása. A visszafordítást egymástól függetlenül, az eredeti szöveg ismerete nélkül két angol anyanyelvü, magyarul magas szinten beszélő, a célnyelvi kultúrát jól ismerő, évtizedek óta Magyarországon élő, nem egészségügyi háttérrel rendelkező fordító végezte. A visszafordításokban azon 3 kérdés esetén találtunk eltérést, amelynél az eredeti angol kifejezésekre - a fogalmi megfeleltetés során - eltérő kifejezést használtak a fordítók, így például: az eredeti 26. kérdés „My PAD makes me feel 'not normal'." esetén, amelynél a magyar tükörfordítás: „A PAD miatt nem érzem magam 'normálisnak'." helyett a fordítói csoport az alábbi megoldás mellett döntött: „Az érszúküuletem miatt nem érzem teljes értékünek magam.”; a mondat visszafordításakor egyértelmüen nem kaptuk vissza az eredeti angol kifejezést.

A protokoll szerinti következő lépés a fordítások szakértői csoport általi megvitatása volt. Beaton és mtsai ajánlása alapján a szakértői csoport tagjai voltak: szakfordítók, két belgyógyász-angiológus szakorvos, egy alkalmazott nyelvész és egy nyelvész. A szakértői csoport a PADQOL állapotfelmérô kérdéseinek nyelvi megfogalmazását jelentéstani és szintaktikai szempontból pontosította, és létrehozta a majdnem végleges, vagyis az úgynevezett ,pre-final” verziót (1. ábra) [24].

A Regionális Etikai Bizottság engedélyének (ügyiratszám: PTE/1750/2019) megszerzését követően megkezdtük a PADQOL ,„pre-final” magyar verziójának pilottesztelését a Pécsi Tudományegyetem, Klinikai Központ, I. Belgyógyászati Klinika, Angiológiai Tanszék járó- és fekvőbeteg-osztályán Fontaine II-IV. stádiumú, PAD-ban szenvedő személyek bevonásával. A 30, pilottesztelésre felkért pácienst a jövőbeli beválasztási kritériumainknak megfelelően választottuk ki, átlagéletkoruk $71,2 \pm 10,4$ év volt (15 nő, 15 férfi). A kognitív interjúkat megelőzően a résztvevők szóbeli és írásbeli tájékoztatást kaptak a vizsgálat céljáról, és beleegyező nyilatkozatot írtak alá. A kognitív interjúkat ún. "think aloud" (hangos gondolkodás) és ,,paraphrasing” (átfogalmazás) technikával folytattuk le, melyek során az instrukciók, a kérdések és a válaszlehetőségek érthetőségét mértük fel [27]. A 30, PAD-ban szenvedő páciens bevonásával folytatott kognitív interjúk során szerzett tapasztalatok alapján elmondható, hogy a PADQOL magyar verziója jól érthető, kitöltése nem okozott nehézséget. Értelmezési probléma a kérdőív 6. tétele esetén merült fel: „Az érszúkületem miatt ért már valamilyen veszteség." állítás esetén az interjúalanyok egy részének nehézséget okozott a ,veszteség” szó értelmezése a PAD kontextusában, különösen a Fontaine II. stádiumú PAD-betegeknél, akiknél a betegség még nem okozott jelentős fájdalmat vagy járási nehézséget: dolgoztak, mindennapi rutintevékenységeikben nem voltak akadályozottak. A pilotvizsgálaton részt vett személyek egy jelentős része a „,veszteség” szó alapján elsősorban anyagi veszteségre asszociált, így különösen azok körében, akiknél a PADot a nyugdíjazásuk utáni időszakban diagnosztizálták, és már nem voltak aktív dolgozók, szintén értelmezési nehézség merült fel. A kognitív interjúk alkalmával felkínált „hátrány” szó, amely korábban a fordítási folyamat során is felmerült mint alternatíva, úgy tûnt, segíti ennek a kérdésnek az értelmezését, így a végső magyar változatban mindkét szó használata mellett döntöttünk, a fogalmi és a szó szerinti ekvivalencia biztosítása érdekében. Tehát a 6. tétel végső magyar verziója az alábbira módosult: „Az érszűlkületem miatt ért már valamilyen hátrány vagy

1. táblázat A pilotpopuláció demográfiai jellemzői, komorbiditási és rizikófaktorokra vonatkozó adatai

\begin{tabular}{lccc}
\hline Változók & $\begin{array}{c}\text { Összesen }(\mathrm{n}=30) \\
\mathrm{n}(\%)\end{array}$ & $\begin{array}{c}\text { Férfi }(\mathrm{n}=15) \\
\mathrm{n}(\%)\end{array}$ & $\begin{array}{c}\text { Nő }(\mathrm{n}=15) \\
\mathrm{n}(\%)\end{array}$ \\
\hline Dohányzás & & & \\
Soha & $9(30)$ & $2(13,3)$ & $7(46,7)$ \\
A múltban & $17(56,7)$ & $10(66,7)$ & $7(46,7)$ \\
Jelenleg & $4(13,3)$ & $3(20)$ & $1(6,7)$ \\
\hline
\end{tabular}

Diabetes

\begin{tabular}{lrrr} 
Igen & $17(56,7)$ & $10(66,7)$ & $7(46,7)$ \\
Nem & $13(43,3)$ & $5(33,3)$ & $8(53,3)$ \\
\hline
\end{tabular}

Hypertonia

\begin{tabular}{cccc} 
Igen & $28(93,3)$ & $14(93,3)$ & $14(93,3)$ \\
Nem & $2(6,7)$ & $1(6,7)$ & $1(6,7)$ \\
\hline
\end{tabular}

Dyslipidaemia

\begin{tabular}{cccc} 
Igen & $28(93,3)$ & $14(93,3)$ & $14(93,3)$ \\
Nem & $2(6,7)$ & $1(6,7)$ & $1(6,7)$ \\
\hline
\end{tabular}

CVD-kórelözmény

\begin{tabular}{cccc} 
Igen & $28(93,3)$ & $14(93,3)$ & $14(93,3)$ \\
Nem & $2(6,7)$ & $1(6,7)$ & $1(6,7)$ \\
\hline
\end{tabular}

Korábbi revascularisatio

\begin{tabular}{rrrr} 
Igen & $9(30)$ & $4(26,7)$ & $5(33,3)$ \\
Nem & $21(70)$ & $11(73,3)$ & $10(66,7)$ \\
\hline
\end{tabular}

Fontaine-skála

\begin{tabular}{lrll} 
II/a & $5(16,7)$ & $2(13,3)$ & $3(20,0)$ \\
II/b & $12(40,0)$ & $7(46,7)$ & $5(33,3)$ \\
III. & $3(10,0)$ & $1(6,7)$ & $2(13,3)$ \\
IV. & $10(33,3)$ & $5(33,3)$ & $5(33,3)$ \\
\hline
\end{tabular}

CVD = szív- és érrendszeri megbetegedés 
Cronbach-alfa-értékek PADQOL-faktoronként a saját eredmé nyek és a Treat-Jacobson-tanulmány szerint

\begin{tabular}{lcc}
\hline Faktor & $\begin{array}{c}\text { Cronbach-alfa } \\
\text { (Saját eredmények) }\end{array}$ & $\begin{array}{c}\text { Cronbach-alfa } \\
\text { (Treat-Jacobson } \\
\text { et al., 2012) }\end{array}$ \\
\hline $\begin{array}{l}\text { 1. faktor: Társas kapcsolatok és } \\
\text { interakciók }\end{array}$ & 0,89 & 0,92 \\
$\begin{array}{l}\text { 2. faktor: Önkép és érzelmek } \\
\begin{array}{l}\text { 3. faktor: Tünetek és testi } \\
\text { funkcióbeli korlátozottság }\end{array}\end{array}$ & 0,88 & 0,89 \\
$\begin{array}{l}\text { 4. faktor: Félelem és bizonyta- } \\
\text { lanság }\end{array}$ & 0,89 & 0,88 \\
\begin{tabular}{l} 
5. faktor: Pozitív adaptáció \\
\hline
\end{tabular} & 0,64 & 0,80 \\
\hline
\end{tabular}

PADQOL = perifériás verőérbetegséggel élők életminősége

veszteség.” A PADQOL kérdőív „,pre-final” verziójának további kérdéseiben értelmezési, tartalmi vagy fogalmi nehézség nem merült fel (1. ábra).

\section{Statisztikai módszerek}

A minta főbb jellemzőit nemek szerinti bontásban, az abszolút és relatív gyakorisági értékek feltüntetésével mutatjuk be (1. táblázat). Az egyes faktorokhoz tartozó összesített és transzformált score-értékek átlagát, szórását, minimum- és maximumértékeit kalkuláltuk (2. táblázat). A mérôeszköz faktorstruktúrájának feltárásához faktoranalízist (fókomponens-elemzés, varimax rotáció) végeztünk, melynek alapján feltártuk a PADQOL kérdő- iv belső struktúráját (3. táblázat). A faktoranalízis eredményei csupán tájékoztató jellegúek, mivel az az előfeltétel, miszerint a változók számánál tízszer több válaszadó szükséges, az alacsony elemszám miatt nem teljesült, továbbá a Kaiser-Meyer-Olkin (KMO)-érték nem haladta meg a 0,5-es kritikus értéket. Az egyes tételekhez tartozó faktorsúlyokat bemutatjuk, mert azok értékei közelítenek az eredeti nyelven történt validálás értékeihez, mutatva a fordítás megfelelőségét. A kérdőív egyes alskáláinak megbízhatóságát a tételek belső konzisztenciáját mutató Cronbach-alfa-együttható kiszámításával vizsgáltuk (2. táblázat). Az elemzésekhez SPSS 23.0 programcsomagot (IBM Corporation, Armonk, NY, Amerikai Egyesült Államok) használtunk.

\section{Eredmények}

\section{A pilotpopuláció demográfiai, komorbiditási és rizikófaktorokra vonatkozó adatai}

A pilotvizsgálatban 15 nő és 15 férfi vett részt. Az átlagéletkor 71,2 \pm 10,4 év, a legfiatalabb beteg 51 , míg a legidősebb 93 éves volt. A legtöbb páciens már nem dohányzik. A válaszadók fele cukorbeteg $(\mathrm{n}=17)$, és 2 fó kivételével a magasvérnyomás-betegség, a dyslipidaemia és a cardiovascularis megbetegedés is fennáll. Korábbi alsó végtagi revascularisatio 9 betegnél történt; a Fontaine-stádiumok tekintetében Fontaine II/b $(\mathrm{n}=12)$ és Fontaine IV. stádium fordult elő $(\mathrm{n}=10)$ a leggyakrabban (1. táblázat).

3. táblázat |A PADQOL-faktorok értékei a pilotmintában $(\mathrm{n}=30)$

\begin{tabular}{|c|c|c|c|c|}
\hline PADQOL-faktor & Átlag (szórás) & Lehetséges terjedelem & Minimum & Maximum \\
\hline 1. faktor, összesített score & $31,97(10,99)$ & $9-54$ & 15 & 54 \\
\hline 1. faktor, transzformált score & $51,04(24,42)$ & $0-100 \%$ & $13,3 \%$ & $100 \%$ \\
\hline 2. faktor, összesített score & $20,90(8,99)$ & $7-42$ & 7 & 37 \\
\hline 2. faktor, transzformált score & $39,71(25,68)$ & $0-100 \%$ & $0 \%$ & $85,7 \%$ \\
\hline 3. faktor, összesített score & $21,13(10,04)$ & $8-48$ & 9 & 48 \\
\hline 3. faktor, transzformált score & $32,83(25,09)$ & $0-100 \%$ & $2,5 \%$ & $100 \%$ \\
\hline 4. faktor, összesített score & $14,07(4,86)$ & $4-24$ & 6 & 24 \\
\hline 4. faktor, transzformált score & $50,33(24,32)$ & $0-100 \%$ & $10 \%$ & $100 \%$ \\
\hline 5. faktor, összesített score & $28,10(6,22)$ & $7-42$ & 13 & 41 \\
\hline 5. faktor, transzformált score & $60,29(17,78)$ & $0-100 \%$ & $17,1 \%$ & $97,1 \%$ \\
\hline 22. item (munka), összesített score & $3,03(1,90)$ & $1-6$ & 1 & 6 \\
\hline 22. item, transzformált score & $40,67(38,05)$ & $0-100 \%$ & $0 \%$ & $100 \%$ \\
\hline 24. item (szexuális funkció), összesített score & $2,67(1,90)$ & $1-6$ & 1 & 6 \\
\hline 24. item, transzformált score & $33,33(29,87)$ & $0-100 \%$ & $0 \%$ & $100 \%$ \\
\hline 25. item (intim kapcsolatok), összesített score & $5,40(1,07)$ & $1-6$ & 2 & 6 \\
\hline 25. item, transzformált score & $88,00(21,40)$ & $0-100 \%$ & $20 \%$ & $100 \%$ \\
\hline
\end{tabular}

PADQOL = perifériás verőérbetegséggel élők életminősége 


\section{Belsö megbizhatóság}

A PADQOL dimenzióinak/faktorainak Cronbach-alfaértéke 0,642 és 0,887 között mozgott a pilotpopulációban, ami hasonló ez eredeti, Treat-Jacobson és mtsai által kifejlesztett és 297 páciens bevonásával validált kérdőív megbízhatósági értékeihez, és a Pozitív adaptáció dimenzió kivételével mindenhol elérte a 0,70 belsô megbízhatósági értéket. Az eredeti kérdőív validálási tanulmányában publikált megbízhatósági értékekhez hasonlóan, az általunk végzett pilotvizsgálat során kitöltött PADQOL ,pre-final” magyar változatának esetén is az 5. Pozitív adaptáció dimenzió megbízhatósági értéke volt a legalacsonyabb (Cronbach- $\alpha=0,642)$ (2. táblázat).

\section{Faktoranalizis}

Az egyes faktorokhoz kapcsolódó score-értékek alapján a Társas kapcsolatok és interakciók (1. faktor) és a Pozitín adaptáció faktor (5. faktor) mutatta a legmagasabb, tehát a legjobb értéket $(31,97$ és 28,10$)$. A Félelem és bizonytalanság faktor (4. faktor) kapta a legalacsonyabb értéket (14,07). A különálló tételek közül az Intim kapcsolatok kérdés fordított értékeléssel számított, így annak magas értéke $(5,4)$ rosszabb statust mutat (3. táblázat).

A faktoranalízis eredményei a feltételek nem teljesülése miatt csupán tájékoztató jellegúek. A faktorsúly minden változó esetében meghaladta a 0,25-os elvárható, minimális értéket, a legalacsonyabb kommunalitás 0,384 volt. A faktorsúlyok hasonló értékeket mutattak, mint az eredeti validáló tanulmány eredményei (4. táblázat).

A PAD szubjektív betegségterhének mérésére kifejlesztett PADQOL önkitöltős életminőség-kérdőív Magyarországra történő lingvisztikai validálását és kultúrközi adaptációját, elővalidált változatának összeállítását sikeresen, nehézségek nélkül végeztük el. A lingvisztikai validálási folyamatot nemzetközileg elfogadott és alkalmazott protokoll alapján folytattuk le. A pilotvizsgálat során meggyőződtünk a kérdő́ív instrukcióinak, kérdéseinek és válaszlehetőségeinek érthetőségéroól; a kognitív interjúk alapján egy kérdésen módosítottunk, majd véglegesítettük a kérdő́iv magyar nyelvú változatát. A pilotvizsgálat alapján elmondható, hogy a kérdőív magyar változata a megbízhatóság szempontjából alkalmas a validálási folyamat (PAD tüneteivel éló nagyobb betegpopuláción történő pszichometriai és klinikometriai vizsgálat) következő lépésének elvégzésére. A végső validálást követően a PADQOL magyar verziója hasznos segítség lehet a PAD-ban szenvedő páciensek életminőségének felmérésében, a kezelések, beavatkozások hatékonyságának a beteg szempontjából történő értékelésében.

\section{Megbeszélés}

Magyarországon eddig nem rendelkeztünk validált, magyar nyelvü, PAD-specifikus életminőség-kérdőívvel.
4. táblázat $\mid$ A PADQOL kérdőív ,ppre-final” magyar verziójának $(\mathrm{n}=30)$ tesztelése során mért faktorsúlyok, tételek és megbízhatósági értékek

Faktorok Magyar faktorsúly (saját eredmények)

1. faktor: Társas kapcsolatok és interakciók

Az érszúkü̈letem nagyon megnehezíti az életemet. $\quad 0,794$

Az érszúkületem nagy teher a számomra. $\quad 0,793$

Az érszúküuletem miatt elszigeteltnek érzem magam. $\quad 0,724$

A családomra is kihat az érszúkülletem. $\quad 0,712$

Az érszúkületem nagyban korlátozza a szabadságomat. $\quad 0,681$

Az érszúkülletem nagyon megváltoztatta az életben $\quad 0,671$

betöltött szerepemet.

Az érszúkületem miatt úgy érzem, terhére vagyok $\quad 0,582$

másoknak.

Az érszúküuletem miatt ért már valamilyen veszteség. $\quad 0,573$

Az érszúkületem rossz hatással van a baráti kapcsolataimra. $\quad 0,512$

2. faktor: Önképés érzelmek

Az érszúkü̈letem miatt nem érzem teljes értékûnek magam.

Nagyon kényelmetlenül érzem magam amiatt, hogy korlátoz az érszúkületem.

Amikor az érszúkületemre gondolok, tehetetlennek

érzem magam.

Úgy érzem, hogy az érszúkületem miatt nagyon sebezhe- $\quad 0,554$

tô vagyok.

Úgy érzem, hogy az érszúkületem miatt már nem vagyok $\quad 0,520$

a régi.

Lehangol, amikor az érszúkületemre gondolok. $\quad 0,490$

Nagyon félek attól, hogy másokra leszek utalva. $\quad 0,384$

3. faktor: Tünetek és testi funkcióbeli korlátozottság

Az érszúkületem miatt sok olyan dolgot nem tudok

0,771

csinálni, ami örömet okoz.

Az érszúkületem nagymértékben korlátozza a tevékenységeimet.

Az érszúkülletem miatt nem tudok annyit sétálni, mint

Járás közben nagyon fáj a lábam az érszúkületem miatt. 0,632

Az érszúküulet sok fájdalmat okoz. $\quad 0,621$

Nagyon zavar az érszúkületem. $\quad 0,569$

Nem tudok lépést tartani a kortársaimmal. $\quad 0,540$

Idősebbnek érzem magam a koromnál. $\quad 0,452$

\begin{tabular}{l} 
4. faktor: Félelem és bizonytalanság \\
\hline Félek, hogy el fogom veszíteni a lábam egy részét vagy az $\quad 0,731$
\end{tabular} egész lábamat.

Félek, hogy az egészségi állapotom rosszabbodni fog az $\quad 0,714$ érszúkületem miatt.

Az érszúküuletem folyamatosan rosszabbodni fog. $\quad 0,519$

Félek, hogy az érszúkületem miatt meghalok. $\quad 0,421$

5. faktor: Pozitív adaptáció

Tisztában vagyok az érszúkületem okaival. $\quad 0,889$

Sikerült úgy változtatnom az életemen, hogy jobban $\quad 0,858$

együtt tudjak élni az érszúkületemmel.

Minden szükségeset meg tudok tenni, hogy kézben

tartsam a betegségemet.

Biztos vagyok benne, hogy megbirkózom mindennel, $\quad 0,801$

amit a jövő hoz.

Bizakodó vagyok az érszúkületemet illetően. $\quad 0,759$

Javul az állapotom. $\quad 0,662$

Az érszúkületem idővel fokozatosan javulni fog. $\quad 0,568$

PADQOL = perifériás verőérbetegséggel élők életminősége 
A validálási engedély megszerzését követően, nemzetközileg elismert és használt protokoll alapján elvégeztük a PADQOL méróeszköz nyelvi validálását és kultúrközi adaptációját. Munkánkkal egy olyan új mérőeszközt kívántunk biztosítani, mellyel a perifériás érbetegek szubjektív betegségterhének még pontosabb mérése és értékelése, a magyar betegeken végzett klinikai beavatkozások hatékonysága, az ezek révén elért életminőség-nyereség a beteg szempontjából is mérhetővé válhat. A PADQOL „pre-final” magyar verzió megfelelően magas Cronbachalfa-értéke és a magas faktorsúlyok az eredeti amerikai tanulmány értékeihez hasonlóak, tehát a kérdőív megbízhatósága megfelelő [19].

Kolossváry és mtsai retrospektív kohorszvizsgálatot végeztek 2004 és 2012 között, egész Magyarországra kiterjesztve, KSH- és EUROSTAT-adatok felhasználásával. A szerzők a PAD következményeként elvégzett alsó végtagi major (boka feletti) amputációk számának változását vizsgálták, és sajnálatos módon azt találták, hogy a vizsgált 9 év során a major alsó végtagi amputációk száma hazánkban nem változott, továbbá hogy az európai standard populációval összehasonlítva is aggasztóan magas volt. A vizsgált 9 év során 38200 major amputációt végeztek hazánkban, melynek incidenciája a teljes populációban 42,3/100 000. Az amputáción átesett betegek 50,4\%-a volt diabeteses [28]. A 2018. évi VASCUNETjelentés szintén rámutat a PAD miatt végzett major amputációk igen magas incidenciájára hazánkban. A $\geq 65$ éves korosztályt vizsgálva hazánkban volt a legmagasabb a major amputációk aránya a teljes populációhoz viszonyítva (41,4/100 000); az amputáció miatt bekövetkező mortalitás $(20,3 \%)$, az aktív dohányosok aránya $(25,8 \%)$ is nálunk volt a legmagasabb [29].

A klinikai orvosi gyakorlatban az életminőség vizsgálata és értékelése arra irányul, hogy rövid, illetve hosszabb távon a betegség és annak kezelése milyen hatással van a páciens fizikai jóllétére, aktivitására, emberi kapcsolataira és lelki egészségére. A tartósan megromlott egészségi állapot ugyanis több szempontból is tragikus lehet az egyén számára, hiszen nemcsak magából a betegségből fakadnak hatások (például fájdalom), de a betegség következtében az egyén akadályozottá válhat a munkavégzésben, és szociális közege is megváltozhat. Nehézségei akadhatnak például a társas kapcsolatok kialakításában és fenntartásában. A betegség tehát nemcsak a testi funkciócsökkenés miatt jelent megterhelést az egyén és a társadalom számára, hanem az élet többi területére kiterjedő „kompetenciaérzést” is negatívan befolyásolja, ami jelentősen csökkenti a szubjektív életminőséget, és az egészségi állapot további romlását okozhatja [30].

A várható élettartam növekedésével az egyének egyre több életévet élnek meg krónikus betegségben, ami jelentős hatással bír életminőségükre. A PAD prevalenciája és incidenciája is jelentős növekedést mutat a kor előrehaladtával. A 60-70 éves korosztályban a növekedés $>10 \%[11,13]$.
A klinikai kutatásokban különböző szempontokból vizsgálják a betegségekkel összefüggő életminőségi változásokat, számos életminőség-kérdőív terjedt el [31, 32]. Az életminőség-vizsgálatok fontos bemeneti adatként szerepelnek a különböző egészségügyi technológiák egészség-gazdaságtani (költség-haszon) elemzésében és betegségteher-felmérésekben [33-37].

Az általános (generikus) kérdőívek az emberek többsége számára szubjektíve fontos dimenziókat vizsgálják egy adott betegség kapcsán (pszichés és szociális jóllét, teljesítőképesség, testi korlátozottság). Életminőségi profilt ad például az SF-36 kérdőív, összesített életminőségi mutató kiszámítását teszi lehetővé például az EuroQol-kérdőív. A betegségspecifikus kérdooívek az adott betegség szempontjából fontos jellegzetes problémákat vizsgálják. A PAD tekintetében a Vascular Quality of Life (VASCUQOL) kérdőív 25 itemet tartalmaz, melyek a szociális és emocionális jóllét, a fájdalomérzet, a tünetek és aktivitás területeit vizsgálják, míg a Walking Impairment Questionnaire (WIQ) elsősorban a beteg szúk környezetében, a mindennapi élete során szükséges járástávolságok megtétele során tapasztalt fájdalomra és akadályozottságra fókuszál: vizsgálja a járássebességet, a járástávolságot és a lépcsőzés során tapasztalt panaszokat, de a PAD pszichoszociális hatásait nem vizsgálja [3, 38, 39]. Egyértelmúvé vált, hogy az életminőségkutatásokban a generikus és betegségspecifikus kérdőívek együttes használatára van szükség $[1,16]$. De Vries és mtsai 2005-ben, prospektív, multicentrikus tanulmány keretében 450 , perifériás verőérbeteg bevonásával végeztek életminőség-felmérést, és kimutatták, hogy az általuk használt betegségspecifikus kérdőív, a Vascular Quality of Life (VASCUQOL) jobban differenciálja az enyhe szemben a súlyos PAD-ot, mint az általános életminőséget mérő kérdőívek (SF-36, EuroQoL-5D), továbbá a 6 hónapos utánkövetési időszak végén elvégzett ismételt felmérés esetén is a VASCUQOL bizonyult a pontosabb mérőeszköznek a terápiás beavatkozások (konzervatív terápia 143, perkután transzlumináris angioplasztika 152, illetve sebészi beavatkozás 91 betegnél) hatékonyságának mérésében [18].

Számos kutatást folytattak a perifériás verőérbetegek életminőség- és betegségteher-mérésére. Hazánkban Balogh és mtsai keresztmetszeti kérdőíves felmérést végeztek 4 magyarországi angiológiai centrumban, összesen 102 beteg bevonásával, az EQ-5D általános életminőség-mérővel, melynek célja a Fontaine II-IV. stádiumú perifériás érbetegek életminőségének és betegségterhének vizsgálata volt. A kutatás eredményeképpen a szerzők azt találták, hogy a súlyosabb állapot, a Fontaine IV. stádium, a nyugalmi ischaemiás fájdalom és ulcus megléte jelentôs életminőség-romlással jár. A PAD-dal élők életminősége a Fontaine-stádiumok mentén rosszabbodik [15].

A perifériás verőérbetegség mind az érintettek és környezetük, mind a társadalom számára jelentős betegségterhet képvisel. A PAD-dal kapcsolatos betegségteher 
teljes körű ismerete, a beavatkozások által elért életminőség-nyereség mérése, a PAD járulékos kockázatainak kivédése, a minor és major amputációk számának csökkentése hazánkban igen jelentôs fontossággal bír, melynek a PADQOL kérdőív egy hasznos mérőeszköze lehet a klinikometriai vizsgálatot követően.

\section{Következtetés}

Létrehoztuk a PADQOL kérdőív végső magyar verzióját, mely méróeszköz érvényes és alkalmas a nyelvi és kultúrközi adaptáció következő lépésének elvégzésére, nagyobb betegpopuláción történő pszichometriai és klinikometriai vizsgálat által a PAD-ban szenvedő betegek életminőségének, szubjektív betegségterhének, a gyógyszeres vagy sebészi kezelések eredményességének felmérésére történő vizsgálat elvégzésére.

Anyagi támogatás: A közlemény az EFOP-3.6.2-162017-00009. számú, „Klinikai kutatások tematikus hálózatának kialakítása és nemzetköziesítése" című pályázat keretében készült.

Szerzôi munkamegosztás: A vizsgálat tervezése és lefolytatása: H. L., B. I., E. D. Nyelvi validálás: H. L., B. I., K. K., K. G., E. D. Klinikai kérdőíves vizsgálat: B. K., F. K., K. K., K. G., E. D. Statisztikai elemzések: H. L., K. Zs., N. N. Irodalomkutatás: H. L., B. I., E. D. A kézirat megszövegezése: H. L., B. I., E. D. A kézirat végleges változatát valamennyi szerző elolvasta és jóváhagyta.

Érdekeltségek: A szerzőknek nincsenek érdekeltségeik.

\section{Köszönetnyilvánítás}

A szerzők ezúton mondanak köszönetet a PADQOL lingvisztikai validálási folyamatában való együttmúködésért Baditz Mihálynak, Vivian Braschnak, dr. Dombi Juditnak, dr. Fekete Adrienn-nek, dr. Lebmann Magdolnának és dr. Andrew C. Rouse-nak, továbbá a pilotvizsgálaton részt vett betegeknek.

Az eredeti angol nyelvú kérdőív használatára, magyarországi adaptációjára engedélyt kaptunk a kérdőív fejlesztőjétől. Ezúton is köszönjük a validálási engedélyt prof. Diane Treat-Jacobsonnak.

\section{Irodalom}

[1] Gulácsi L, Brodszky V, Landi A, et al. The significance of measuring quality of life in peripheral artery disease. [Az életminóség mérésének jelentősége perifériás verőérbetegségben.] Érbetegségek 2011; 18(Suppl 2): 28. [Hungarian]

[2] Járai Z. Critical limb ischaemia - the most severe form of peripheral artery disease. [A kritikus végtagischaemia - a perifériás verőérbetegség legsúlyosabb formája.] Magyar Orvos 2008; 16: 39-41. [Hungarian]

[3] Regensteiner J, Steiner JF, Panzer RJ, et al. Evaluation of walking impairment by questionnaire in patients with peripheral artery disease. J Vasc Med Biol. 1990; 2: 142-152.

[4] Sagar SP, Brown PM, Zelt DT, et al. Further clinical validation of the walking impairment questionnaire for classification of walk- ing performance in patients with peripheral artery disease. Int J Vasc Med. 2012; 2012: 190641.

[5] Fowkes FG, Rudan D, Rudan I, et al. Comparison of global estimates of prevalence and risk factors for peripheral artery disease in 2000 and 2010: a systematic review and analysis. Lancet 2013; 382: 1329-1340.

[6] Aboyans V, Ricco JB, Bartelink MEL, et al. 2017 ESC Guidelines on the Diagnosis and Treatment of Peripheral Arterial Diseases, in collaboration with the European Society for Vascular Surgery (ESVS). Eur Heart J. 2018; 39: 763-816 .

[7] Pécsvárady Zs. Peripheral artery disease and the complex cardiovascular prevention. [Perifériás artériás betegség és a komplex cardiovascularis prevenció.] Érbetegségek 2007; 14: 77-86. [Hungarian]

[8] Késmárky G, Koltai K, Biró K, et al. Non-invasive diagnostic procedures in peripheral artery disease. [Alsóvégtagi perifériás verőérbetegségek noninvazív diagnosztikája.] Cardiol Hung. 2018; 48: 206-210. [Hungarian]

[9] Pécsvárady Zs. Examination methods of peripheral artery disease in angiology practice. [A perifériás érbetegség vizsgálati lehetôségei az angiológiai gyakorlatban.] Metabolizmus 2008; 6: 86-91. [Hungarian]

[10] Criqui MH, Langer RD, Fronek A, et al. Mortality over a period of 10 years in patients with peripheral artery disease. N Eng J Med. 1992; 326: 381-386.

[11] Criqui MH, Aboyans V. Epidemiology of peripheral artery disease. Circ Res. 2015; 116: 1509-1526.

[12] Guidelines on the treatment of peripheral artery disease of the Ministry of Human Capacities. [Az Emberi Erőforrások Minisztériuma szakmai irányelve a perifériás verőér megbetegedések ellátásáról.] Egészségügyi Közlöny 2017; 66(3): 650-676. [Hungarian]

[13] Meijer WT, Hoes AW, Rutgers D, et al. Peripheral arterial disease in the elderly: the Rotterdam Study. Arterioscler Thromb Vasc Biol.1998; 18: 185-192.

[14] Falnita LS, Cocora M, Nechifor D, et al. Quality of life in patients with peripheral arterial disease before and after surgical treatment. TMJ 2004; 54: 346-353.

[15] Balogh O, Péntek M, Gulácsi L, et al. Quality of life and burden of disease in peripheral arterial disease: a study among Hungarian patients. [Magyarországi perifériás verőérbetegek életminőség és betegségteher vizsgálatának eredményei.] Orv Hetil. 2013; 154: 464-470. [Hungarian]

[16] Brodszky V, Gulácsi L, Landi A, et al. The impact of peripheral artery disease on quality of life. [A perifériás verőérbetegség hatása az életminőségre.] Érbetegségek 2011; 18(Suppl 2): 24-25. [Hungarian]

[17] Farkas K, Kolossváry E, Járai Z. Simple assessment of quality of life and lower limb functional capacity during cilostazol treatment - results of the SHort-tERm cIlostazol eFFicacy and quality of life (SHERIFF) study. Vasa 2020; 49: 235-242.

[18] De Vries M, Ouwendijk R, Kessels AG, et al. Comparison of generic and disease-specific questionnaires for the assessment of quality of life in patients with peripheral arterial disease. J Vasc Surg. 2005; 41: 261-268.

[19] Treat-Jacobson D, Lindguist RA, Witt DR, et al. The PADQOL: development and validation of a PAD-specific quality of life questionnaire. Vasc Med. 2012; 17: 405-415.

[20] Kullmann T, Kullmann L. Taking patients' views into consideration at planning and evaluating care. Patient Reported Outcomes. [A páciensek véleményének figyelembevétele az egészségügyi ellátás tervezése és értékelése során. A páciensek egészségértékelése.] Orv Hetil. 2018; 159: 215-222. [Hungarian]

[21] Fábián B, Csiki Z, Bugán A. Quality of life of patients with Raynaud's disease. [Raynaud-szindrómás betegek életminőségének jellemzői.] Orv Hetil. 2018; 159: 636-641. [Hungarian] 
[22] Poór AK, Sárdy M, Cserni T, et al. Assessment of health-related quality of life in psoriasis patients in Hungary. [Psoriasisban szenvedő betegek életminőségének vizsgálata Magyarországon.] Orv Hetil. 2018; 159: 837-846. [Hungarian]

[23] Wild D, Grove A, Martin M, et al. Principles of good practice for the translation and cultural adaptation process for patient-reported outcomes (PRO) measures: report of ISPOR Task Force for Translation and Cultural Adaptation. Value Health 2005; 8: 94-104.

[24] Beaton DE, Bombardier C, Guillemin F, et al. Guidelines for the process of cross-cultural adaptation of self-report measures. Spine 2000; 25: 3186-3191

[25] Horváth L, Endrei D, Biró K, et al. Validation process of the Peripheral Artery Disease Quality of Life (PADQOL) questionnaire into Hungarian. [A Peripheral Artery Disease Quality of Life (PADQOL) életminőség kérdőív magyar változatának validálási folyamata.] Érbetegségek 2019; 26(Suppl 2): 63. [Hungarian]

[26] Horváth L, Boncz I, Németh N, et al. Cross-cultural adaptation and validation of the Peripheral Artery Disease Quality of Life (PADQOL) questionnaire into Hungarian - piloting results. Value Health 2019; 22(Suppl 3): S567.

[27] Willis GB. Cognitive interviewing and questionnaire design: a Training Manual. Cognitive Methods Staff, Working Paper Series, No. 7. National Center for Health Statistics, Hyattsville, MD, 1994.

[28] Kolossváry E, Ferenci T, Kováts T, et al. Trends in major lower limb amputation related to peripheral arterial disease in Hungary: a nationwide study (2004-2012). Eur J Vasc Endovasc Surg. 2015; 50: 78-85. [Erratum: Eur J Vasc Endovasc Surg. 2019; 58: 783.]

[29] Behrendt CA, Sigvant B, Szeberin Z, et al. International variations in amputation practice: a VASCUNET report. Eur J Vasc Endovasc Surg. 2018; 56: 391-399.

[30] Kopp M, Pikó B. Psychological, sociological and cultural dimensions of health related quality of life. In: Kopp M, Kovács EM. (eds.) The quality of life of the Hungarian population at the millenium. [Az egészséggel kapcsolatos életminőség pszichológiai, szociológiai és kulturális dimenziói. In: Kopp M, Kovács EM. (szerk.) A magyar népesség életminősége az ezredfordulón.] Semmelweis Kiadó, Budapest, 2006; pp. 10-19. [Hungarian]

[31] Kaló Z, Péntek M. Measuring quality of life. In: Gulácsi L. (ed.) Health economics. [Az életminőség mérése. In: Gulácsi L. (szerk.) Egészség-gazdaságtan.] Medicina Könyvkiadó, Budapest, 2005; pp. 161-189. [Hungarian]

[32] Péntek M. Valuing health, health related quality of life. In: Gulácsi L. (ed.) Health economics and technology assessment. [Az egészség értékelése, az egészséggel összefüggő életminőség. In: Gulácsi L. (szerk.) Egészség-gazdaságtan és technológiaelemzés.] Medicina Könyvkiadó, Budapest, 2012; pp. 95-133. [Hungarian]

[33] Endrei D, Zemplényi A, Molics B, et al. The effect of performance-volume limit on the DRG based acute care hospital financing in Hungary. Health Policy 2014; 115: 152-156.

[34] Boncz I, Nagy J, Sebestyén A, et al. Financing of health care services in Hungary. Eur J Health Econ. 2004; 5: 252-258.

[35] Endrei D, Molics B, Ágoston I. Multicriteria decision analysis in the reimbursement of new medical technologies: real-world experiences from Hungary. Value Health 2014; 17: 487-489.

[36] Boncz I, Evetovits T, Dózsa C, et al. The Hungarian Care Managing Organization Pilot Program. Value Health Reg Issues 2015; 7: 27-33.

[37] Boncz I, Sebestyén A. Financial deficits in the health services of the UK and Hungary. Lancet 2006; 368: 917-918.

[38] Morgan MB, Crayford T, Murrin B, et al. Developing the Vascular Quality of Life Questionnaire: a new disease-specific quality of life measure for use in lower limb ischaemia. J Vasc Surg. 2001; 33: 679-687.

[39] Nikolaï SP, Kruidenier LM, Rouwet EV, et al. The Walking Impairment Questionnaire: an effective tool to assess the effect of treatment in patients with intermittent claudication. J Vasc Surg. 2009; 50: 89-94.

(Horváth Lilla, Pécs, Vörösmarty M. u. 3., 7621 e-mail: lilla.horvath@etk.pte.hu)

\section{"Vultu an natura sapiens sis, multum interest." (Nagy különbség, hogy bölcsnek születtél, vagy csak annak látszol.)}

A cikk a Creative Commons Attribution 4.0 International License (https://creativecommons.org/licenses/by/4.0/) feltételei szerint publikált Open Access közlemény, melynek szellemében a cikk bármilyen médiumban szabadon felhasználható, megosztható és újraközölhető, feltéve, hogy az eredeti szerző és a közlés helye, illetve a CC License linkje és az esetlegesen végrehajtott módositások feltüntetésre kerülnek. (SID_1) 